\title{
Observations on the morphology and vegetative cell division of the diatom Donkinia recta
}

\author{
Eileen J. Cox * \\ Biologische Anstalt Helgoland (Litoralstation); \\ D.2282 List/Sylt, Federal Republic of Germany
}

\begin{abstract}
Wild and cultured material of Donkinia recta (Donk.) Grun. has been examined using light microscopy, and both the structure of the living cell and its vegetative cell division are described. Unlike most naviculoid diatoms, D. recta has four chloroplasts per cell, each with four oblong pyrenoids, and division of the chloroplasts follows rather than precedes mitosis and cell division. These two unusual features are probably linked. The species is briefly discussed in relation to other naviculoid taxa in the light of these findings.
\end{abstract}

\section{INTRODUCTION}

Although rarely abundant, Donkinia recta (Donk.) Grun. is an easily recognised diatom, occurring on sandy beaches along North Sea coasts. Its taxonomic treatment, however, has varied. Some authors e.g. van Heurck (1896), Hendey (1964) recognise Donkinia Ralfs (Pritchard, 1861) as a valid genus, while others place its member species in Pleurosigma W.Sm. (Peragallo \& Peragallo, 1897-1908), or in Gyrosigma Hassall (Cleve, 1894; VanLandingham, 1969). Similarly it has been considered related to Pleurosigma and Gyrosigma on the one hand, and to Tropidoneis Cleve and Amphiprora Cleve on the other. Members of Donkinia have a sigmoid raphe (cf. Pleurosigma and Gyrosigma) although the valvar outline is barely sigmoid, while the raphe is raised on a ridge (cf. Tropidoneis and Amphiprora), and in girdle view the cells are centrally constricted. However, there is very little published information on the genus, and living material has only been described by Karsten $(1899,1928)$ and Mereschkowsky (1902-1903). Although neither illustrated living cells both reported that they have four chloroplasts per cell, with pyrenoids according to Mereschkowsky (1902-1903), without according to Karsten $(1899,1928)$. Both suggested that Donkinia is related to Tropidoneis; Mereschkowsky (1902-1903) considered that it represents a transition from Navicula to Tropidoneis, Karsten (1928) placed it between Tropidoneis and Amphiprora in his systematic treatment of genera.

The widespread occurrence of $D$. recta on the shores of the Wadden Sea off the North Sea island of Sylt, in autumn 1980, and its subsequent growth in culture, facilitated a detailed investigation of its vegetative structure and cell division, valvar structure and

\footnotetext{
-Present address: Botany School, South Parks Road, Oxford, OX1 3RA, U.K. 
variation over a period of time. A difference in the timing of chloroplast division in the cell cycle, compared to other naviculoid diatoms was discovered. The vegetative cell division is therefore described and the possible significance of the variation from the normal pattern discussed. The results of frustular studies and long term growth studies will be described and discussed elsewhere.

\section{MATERIALS AND METHODS}

Living material of Donkinia recta was collected from a number of sites around the island of Sylt, off the north west coast of Germany, in the autumn of 1980. Cells were grown in F2 medium (McLachlan, 1973) in plastic petri dishes, at $15^{\circ} \mathrm{C}$ in a light-dark regime of $14 \mathrm{~h}$ light, $10 \mathrm{~h}$ dark, with light intensity between 1400 and 2000 lux.

Examination of living cells was conducted using a Leitz Ortholux microscope with sea-water immersion objectives, and photographed on Agfa Ortho film. Other material was fixed, either in dilute glutaraldehyde or chromic acid, and cell contents examined, with or without the aid of cytological stains, e.g. alizarin green, Delafield's haematoxylin, nuclear red and Sudan IV.

\section{RESULTS}

\section{Vegetative cell morphology}

In valve view, cells of Donkinia recta are linear, with acute to sub-acute, oppositely deflected apices. At each apex one valve margin subtends a larger angle with the apical axis than does the other, the raphe lying closer to the former (Fig. 1: 1, 4). The raphe is sigmoid (Fig. 1: 1,4) and raised upon a ridge for most of its length, except near the central nodule. As a result, in girdle view the more or less rectangular outline is centrally constricted (Fig. 2: 1). Valves are $70-150 \mu \mathrm{m}$ long, 10-20 $\mu \mathrm{m}$ wide, and the girdle is usually 20-30 $\mu \mathrm{m}$ deep. The girdle consists of two unmarked bands (Fig. 3: 8-10; Fig. 4: $3)$, each about $12 \mu \mathrm{m}$ wide, and the depth of the frustule varies with the stage in the life cycle and the degree of overlap of the two bands. Immediately after cell division cells are about $20 \mu \mathrm{m}$ deep, just before the following cell division they may be almost $40 \mu \mathrm{m}$ deep, when the band overlap is minimal. It is possible to see that the valve is finely striated and has a deep mantle (Fig. 2; 1-3; Fig. 3).

Each cell has four plate-like chloroplasts which have four pairs of lobes along their longer margins (Fig. 2: 1), these being further dissected and extending onto the valve face (Fig. 1:1) except where this is crossed by the raphe. The chloroplasts lie along the girdle, each occupying approximately one quarter of the perimeter, from opposite the nucleus to the apex (Fig. 1: 2,3). Thus two plastids along one margin may be considered the equivalent of one plastid in most Navicula species (cf. Cox, 1981; Karsten, 1899, 1928; Mereschkowsky, 1902-1903). Henceforth, when a pair of plastids is referred to, they are the two on one side of the cell, derived from a single plastid, as described later. Along the centre of each plastid, with the major lobes opposite them, are four oblong refractive bodies (Fig. 2: 1). These are inclined at approximately $45^{\circ}$ to the plastid axis, along the plastid and into the cell lumen (Fig. 1: 3), towards one apex in one pair, the opposite in the other. Differential staining with alizarin green and nuclear red, plus 
staining with Delafield's haematoxylin indicate that these are pyrenoids. (Rarely three or five pyrenoids per plastid were observed.)

As in most naviculoid diatoms the nucleus lies in the cytoplasmic connection across the centre of the cell (Fig. 1:2). Two large vacuoles are present, one bctwcen the nucleus and each apex (Fig. 1:2,3). Oil droplets may also be present, more commonly when the cells have been cultured than in the wild.

\section{Cell division}

For the first few months of growth in culture cell division occurred during the latter part of the dark period, although later more cells were found dividing during the light phase. Before the onset of cell division, the cell expands to its maximum volume, the girdle band overlap being reduced to allow this, the chloroplasts become less lobed and more rounded (Fig. 2: 2) and the pyrenoids are less obvious.

The plastids of each pair move in opposite directions, one into each valve (Fig. 2: 3-7), so that the girdle is vacated (Fig. 2: 6) and two ellipsoidal plastids, one from each
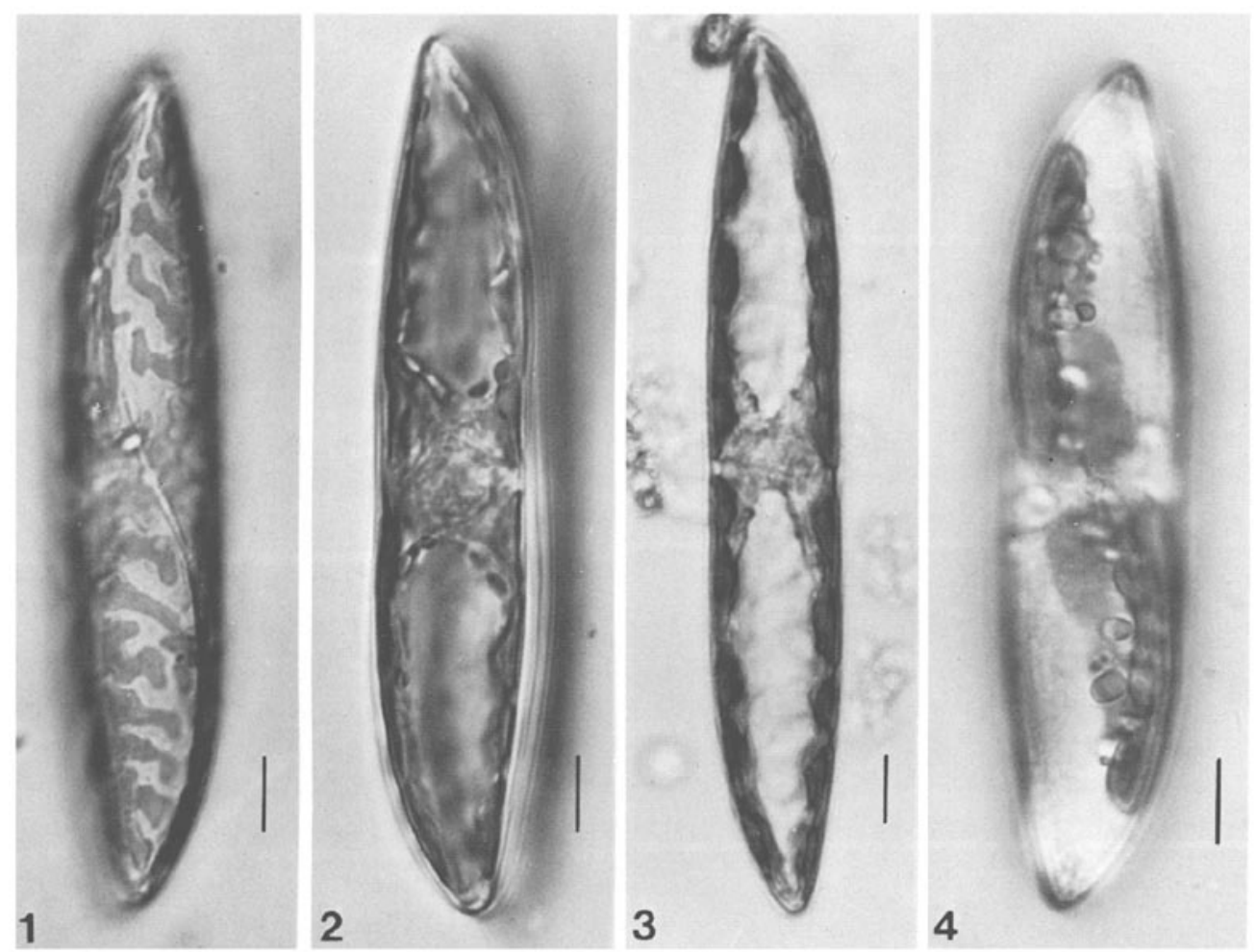

Fig. 1. Light micrographs of valve views of Donkinia recta. All scale lines represent 10 $4 \mathrm{~m}$. 1: Sigmoid raphe and the lobes of the plastids under the valve fare. The valve strine are also visible 2 . Centrally located mucleus, with two large vacuoles, one between the nucleus and each apex. 3 : Pyrenoids inclined into the cell lumen and to one apex along ono side, the other on the opposite side of the valve. 4: Pastids during cell division in the valvar region, diagonally positioned across the 

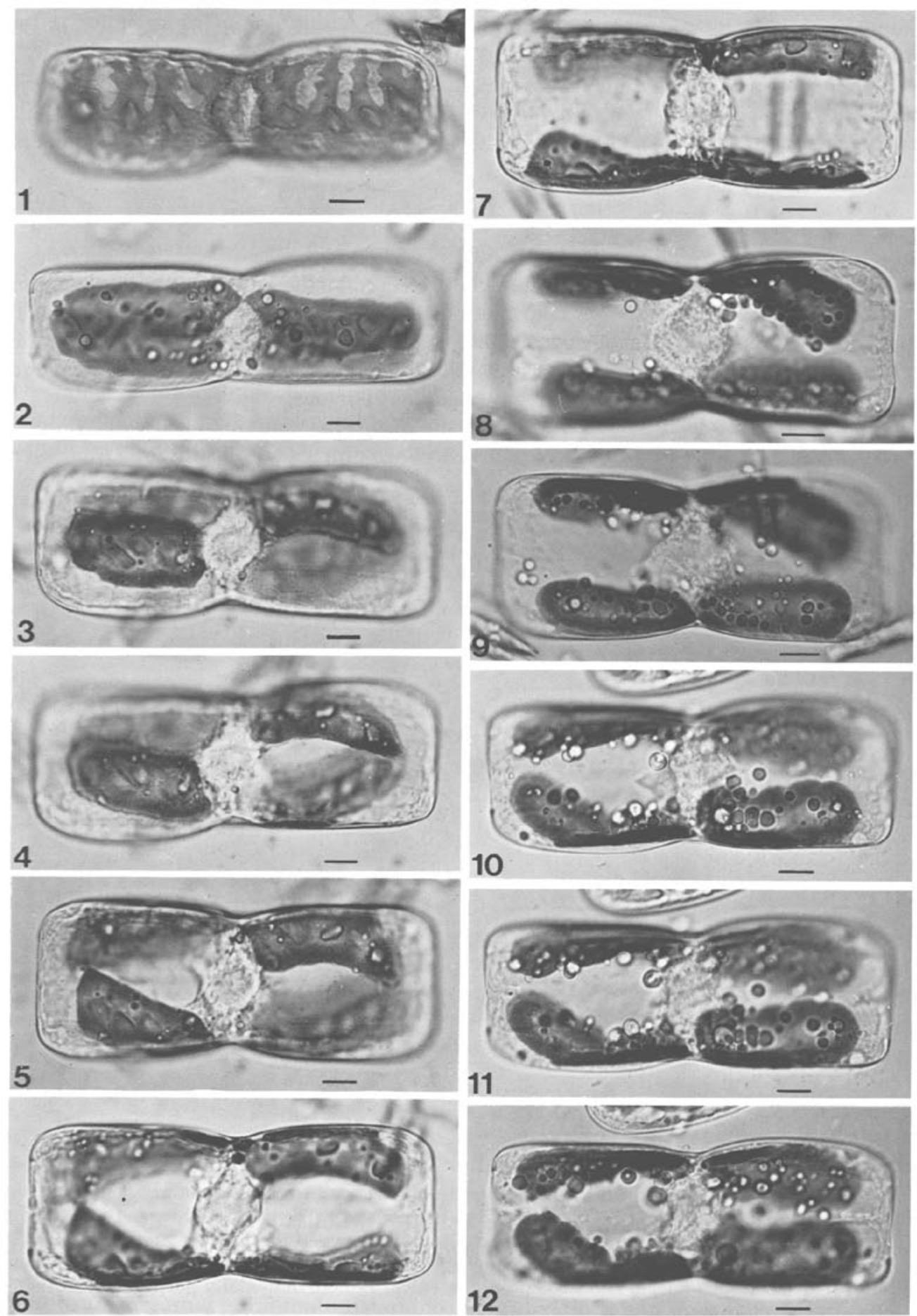
pair lie in each valvar region (Fig. 2: 7). If seen in valve view the plastids under each valve lie diagonally opposite each other with the central cytoplasm between (Fig. 1:4). All four are clearly visible in girdle view (Fig. 2: 6-8). The nucleus is more easily seen at the centre of the cell (Fig. 2: 7), often with a conspicuous nucleolus (Fig. 2:6,8) and the dictyosomes are more obvious (Fig, $2 ; 8$ ). This phase usually takes about two hours.

In living material it is often difficult to see the chromosomes, but the metaphase plate lies at a slight angle to the valvar plane (Fig. 2: 9-11; Fig. 3: 1). During anaphase chromosomes are more easily seen (Fig. 2: 11, 12; Fig. 3: 2-4). Invagination of the plasmalemma begins in anaphase (Fig. 2: 11, 12, Fig. 3: 2-5) and cytokinesis follows quite quickly (Fig. 3: 6, 7), often completed in 5-10 min. Plasmalemma invagination is seen most clearly as it proceeds from pole to centre (Fig. $3: 2-6$ ), but it is also moving in from side to side, i.e. centripetally (Fig. 4:4-6), not in a scissor-like manner. As the central cytoplasm becomes dumb-bell shaped at late anaphase and early telophase (Fig. 3: 5-7; Fig. 4:5,6) the plasmalemma bisects this and cytokinesis is complete (Fig. 3:7). While the daughter nuclei pass through telophase to interphase (Fig. 3: 8-11), the shape of the cytoplasm around them changes, the extent of the contact with each plasmalemma increases and cell wall deposition begins (Fig. 3:7-9). Vesicles can be seen in the region of the plasmalemmae as this proceeds (Fig. 3: 9-11).

As telophase is reached and the silica wall is being laid down, the chloroplasts move so that they lie one along each side of the daughter cells (Fig. 3: 8-10), they elongate apically (Fig. 3: 11), become more lobed (Fig. 3: 12; Fig. 4:1) and divide transversely at the middle (Fig. 4: 2,3) to restore the original number of four. As the plastids regain their lobed outline, the pyrenoids again become conspicuous (Fig. 3: 12; Fig. 4: 1-3) showing the same orientation in both daughter cells, and finally the daughter cells separate. Simultaneously with the restoration of normal chloroplast morphology the nucleus moves from the hypovalvar region to a more central position in the cell (Fig. 3: 11, 12; Fig. 4: 1,2). Formation of the hypocingulum is the last stage in the process and may occur after cell separation. The complete sequence, i.e. redistribution of chloroplasts, mitosis, cytokinesis, new valve formation and reorganisation of the cellular contents, takes about $6 \frac{1}{2} \mathrm{~h}$, of which only $20-30 \mathrm{~min}$ is required for mitosis and cytokinesis.

\section{DISCUSSION}

As mentioned before, Donkinia recta is unusual in having four plastids per cell, and in the timing of chloroplast division in the cell cycle. A few other species are known with four plastids per frustule, but their cell division has not been described.

Fig. 2. Light micrographs of girdle views of Donkinia recta. All scale lines represent $10 \mu \mathrm{m}$. Times of photographs given in brackets. 1: Vegetative cell showing the lobed plastids with the rectangular pyrenoids visible, inclined towards one apex. 2-7: Showing the migration of the chloroplasts and the pyrenoids, visible prior to mitosis. 2. Plastids rounded up. 3-7: Movement towards valvar regions, each plastid of a pair moving in opposite directions. $(3: 00 \mathrm{~min} ; 4: 12 \mathrm{~min} ; 5: 25 \mathrm{~min} ; 6: 38$ $\min _{i} 7: 81 \mathrm{~min}$ ). 8, 9: Prophase - metaphase. 8: Cell in prophase, nucleolus, and dictyosomes near the nucleus in the epivalve, visible $(00 \mathrm{~min})$. 9: Metaphase plate at an angle to the valvar plane $(01$ min). 10-12: Metaphase - anaphase. 10: Metaphase with the chromosomes at the metaphase plate visible (00 min). 11: Early anaphase - metaphase plate disappearing and the invagination of the plasmalemma beginning $(05 \mathrm{~min})$. 12: Anaphase - movement of the chromosomes to the poles (06 

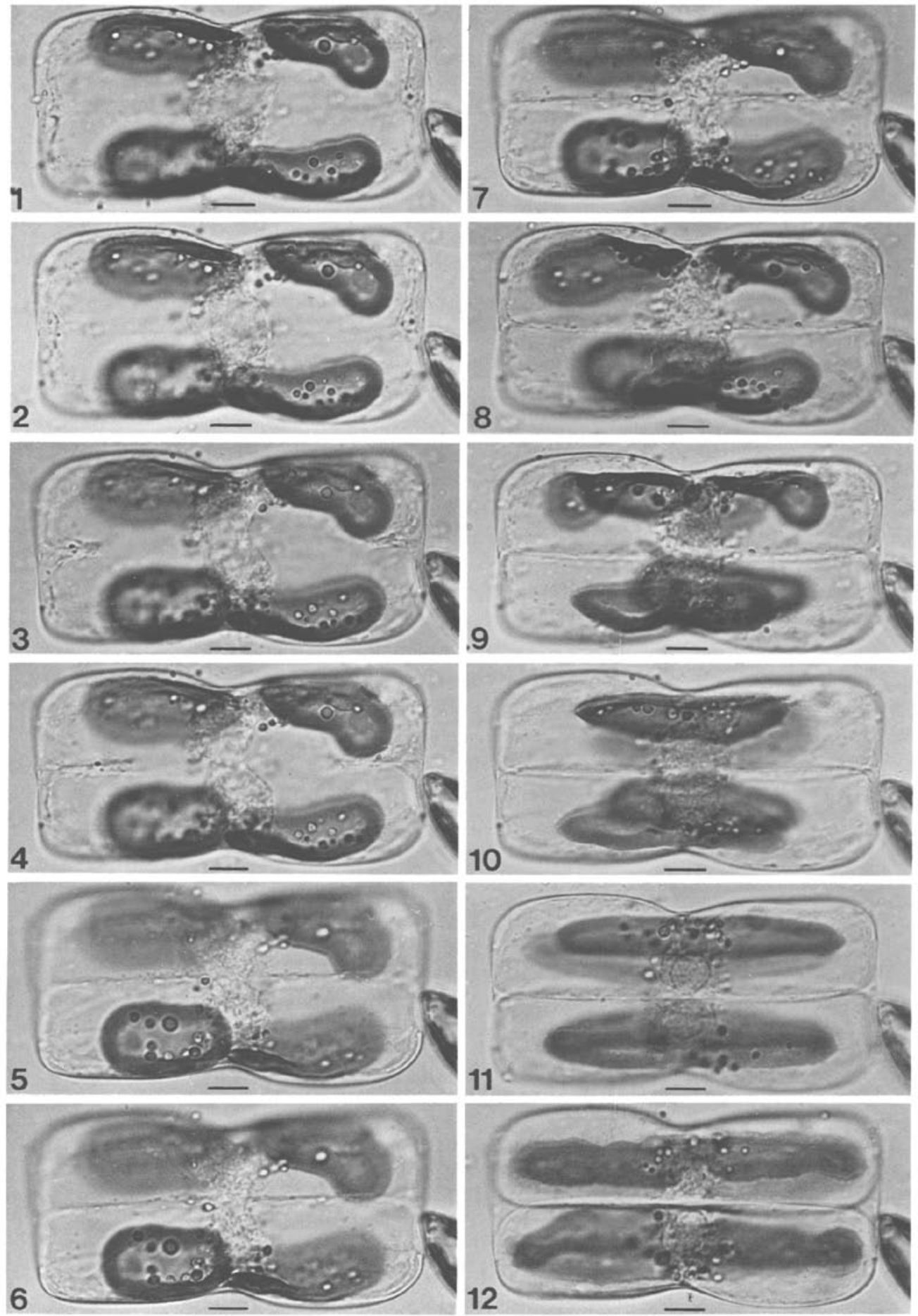

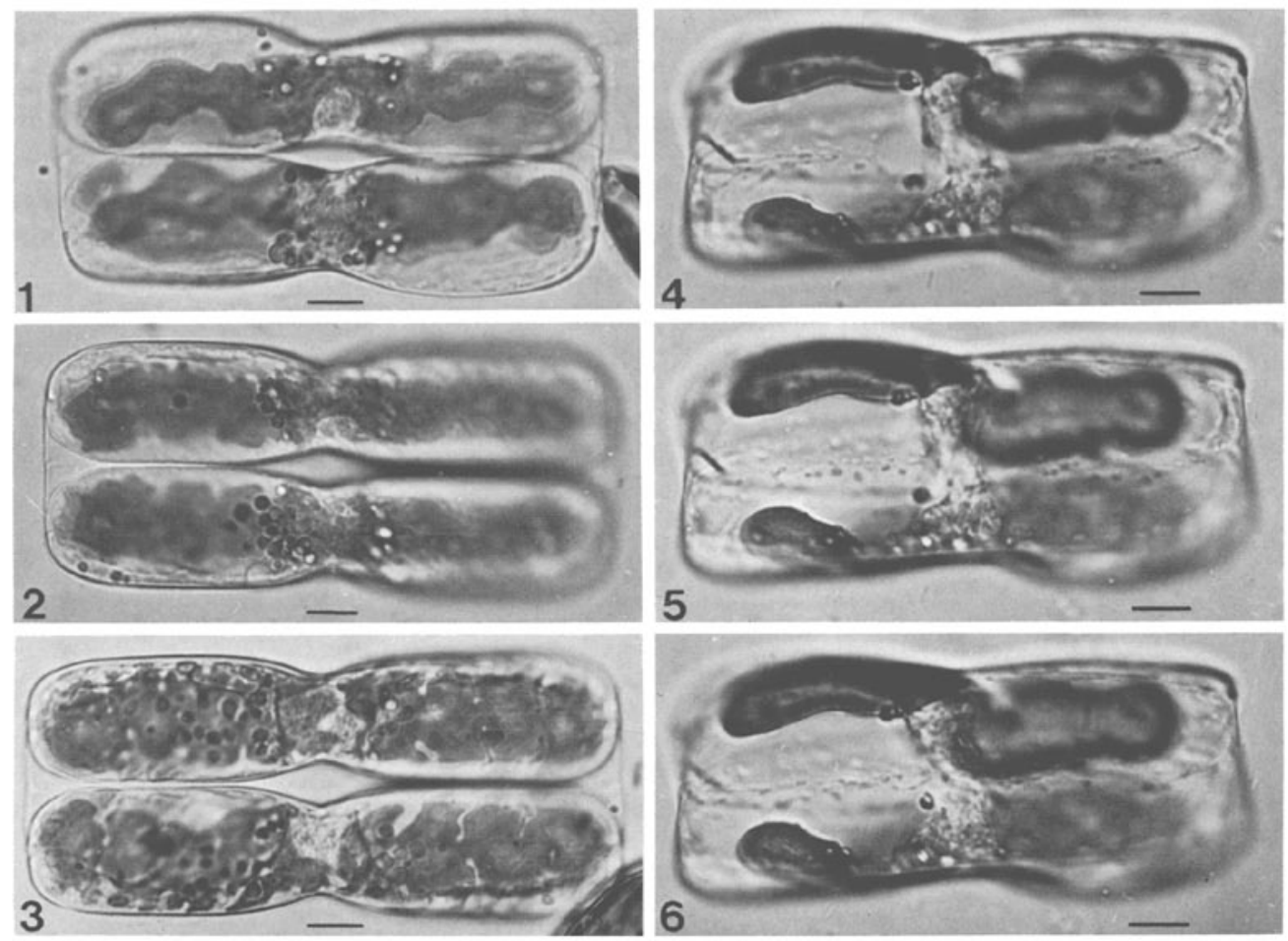

Fig. 4. Light micrographs of girdle views. All scale lines reprosent 10 um. Times of photographs given in brackets. 1-3: Plastid division. 1: Deep central invagination of the plastid visible and four pyrenoids visible in each half (164 min). 2: Division of plastids almost complete. 3: Two daughter cells shortly before their separation. 4-6: Anaphase and cytokinesis showing vesicular activity beside the plasmalemma and the centripetal mode of its invagination (4:00 min; 5: $01 \mathrm{~min} ; 6: 03$ min)

Fig. 3. Mitosis and cell division. All scale lines represent $10 \mu \mathrm{m}$. Times of photographs given in brackets. 1: Metaphase, showing the metaphase plate inclined to the valvar plane (00 min). 2: Early anaphase (05 min). 3: Anaphase - the chromosomes are visible as they move to the poles. Plasmalenum invagination beginning $(07 \mathrm{~min})$. 4: Anaphase - chromosomes almost at the poles and invagination progressing $(08 \mathrm{~min})$, 5: Telophase - invagination approaching the central cytoplasm $(09 \mathrm{~min})$. 6 : Telophase - cytokinesis almost complete $(11 \mathrm{~min})$. 7: Telophase -.. cytokinesis complete; note the vesicular activity beside the plasmalemmae $(14 \mathrm{~min})$. 8: Nuclei going into interphase and wall doposition beginning. The contact between the central cyloplasm and plasmalemma in each cell is greater and chloroplast movement beginning again (25 min). 9 : Continuation of wall deposition and chloroplast realignment $(28 \mathrm{~min})$. 10: Chloroplasts more of less in lite centre of each girdle, daughter nuclei condensing $(36 \mathrm{~min})$. 11: Elongation of chloroplasts occurring, daughtor nuclei in interphase and the central cytoplasm narrower (58 min). 12: Chloroplasts fully extended along girdles and becoming lobed. Pyrenoids reappearing (109 min). 
Normally in naviculoid diatoms plastid division occurs before mitosis and where there is only one plastid per cell clearly this is essential, as cytokinesis follows quickly after mitosis. Usually in a cell with two plastids one moves to each valve and they divide more or less transversely before the start of mitosis. Nuclear and cell division follow, and when these are complete the plastids in the daughter cells migrate so that one lies along each side of the cell. Often the transverse division of the plastids is somewhat oblique (Geitler, 1979; Thaler, 1972; Cox, unpubl.), the behaviour showing a definite right- or left-handedness, as in other phenomena associated with reproduction in pennate diatoms (Geitler, 1979; Rudzki, 1964). In Donkinia the position of the plastids in each valvar region prior to cell division is also diagonal, across the apical axis.

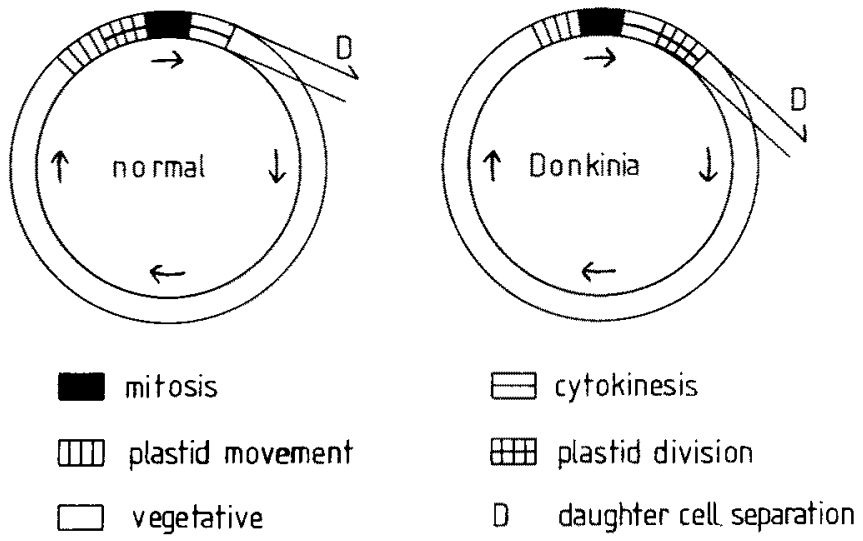

Fig. 5. Diagram to show the sequence of events in the cell cycle of a typical naviculoid diatom and of Donkinia recta. (Not to a time scale)

Chloroplast division prior to mitosis and cytokinesis is essential in species with only one plastid per vegetative cell if both daughter cells are to contain chloroplasts, although for cells with two plastids, their division could, theoretically, occur before or after cytokinesis. Geitler (1977) reported one Eunotia species in which the chloroplasts divide after cell division although other Eunotia species show pre-mitotic plastid division. When, as in Donkinia, four plastids are present in the vegetative cell, post-mitotic division means there are never more than four plastids in a cell, which must certainly simplify redistribution of organelles during cell division. How such a change in timing came about is a matter of speculation.

One explanation would be that the timing of division became steadily earlier in the cell cycle so that what had been a pre-mitotic condition became the vegetative state, i.e. the time between cell division and the following chloroplast division was shortened (see Fig. 5). This explanation demands concomitant changes in chloroplast position after division and before mitosis. The other possibility is that post-cytokinetic plastid division occurred as these were becoming more lobed, from an original two plastid condition, and that the following pre-mitotic division was suppressed. This would not require further reorientation of the plastids, but does assume that somehow the cell controls the number of plastid divisions between successive mitoses. Perhaps examination of the cell cycles of other species with four plastids will shed light on this issue. It is worth noting that the 
plastids in Donkinia rarely move completely under the valve face as they can in other genera, e.g. Navicula, Gyrosigma, but this is unnecessary in Donkinia because its deep valve mantle allows accomodation of the plastids, such that the girdle region is not occupied while cell division is proceeding. Plastid movement is almost entirely in one plane, and is shown diagrammatically in Fig. 6.

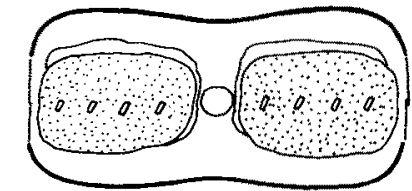

1

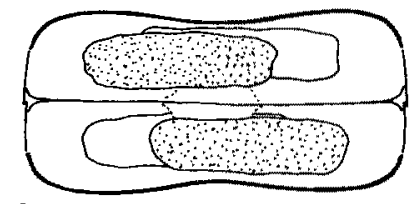

4

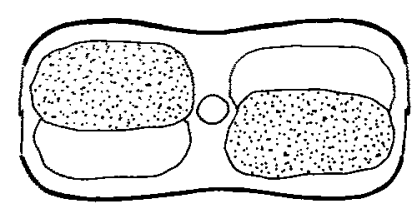

2

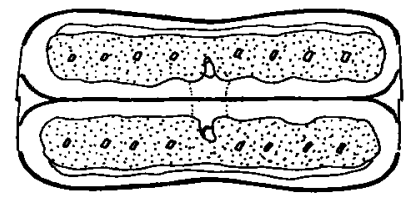

5

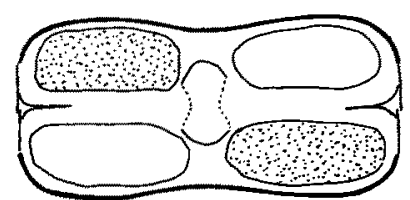

3

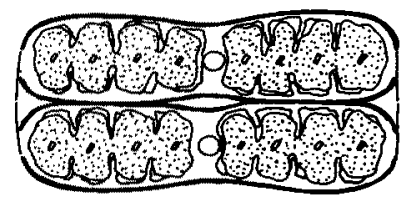

6

Fig. 6. Diagram to show the movement of the plastids and their division. Stippling indicate the two plastids from one pair and their descendants

The number and distribution of chloroplasts in Donkinia shows some similarity to Tropidoneis (Cox, unpubl.), although Schütt (1896) reported that the latter had only two plastids, and Karsten $(1899,1928)$ reported two or four. Tropidoneis also has its raphe raised upon a ridge, albeit straight not sigmoid. Plastids with highly dissected margins have been observed in $G$. balticum (Ehrenb.) Cleve (Cox, unpubl.), although the latter has only two per cell, but the cells are sigmoid unlike Tropidoneis. Geitler (1937) described obliquely orientated pyrenoids in the plastids of Gyrosigma species, but rectangular pyrenoids have previously only been reported for Mastogloia grevillii W.Sm. (Stoermer et al,,1964). The pyrenoids in Donkinia are indistinct during mitosis, particularly between metaphase and telophase, reappearing clearly only as the chloroplasts elongate and then divide. They are presumably replicating during this time, prior to plastid division, since before its completion four pyrenoids are present in each half of the plastid. Confirmation of this requires further investigation, possibly involving electron microscopy.

Thus a study of living material of Donkinia has revealed unusual features for a naviculoid diatom, and ones which link it with both Gyrosigma and Tropidoneis. Although it has sigmoid symmetry, Gyrosigma is usually placed firmly in the Naviculaceae, but Tropidoneis, in having a keeled raphe, shows some similarity to Amphiprora. The latter has a canal raphe (Paddock \& Sims, 1977) and thus shows parallels with members of the Epithemiaceae, Nitzschiaceae and Surirellaceae, but it has only one large chloroplast according to Karsten $(1899,1928)$ and Mereschkowsky (1902-1903). Whether Donkinia is related to other keeled diatoms must await fuller investigations in which studies of living material must play an integral part. It certainly seems likely that other variants on the basic pattern of cell division in diatoms remain to be studied and described. 
Acknowledgements. This work was carried out while the author was the holder of a Fellowship from the Royal Society, as part of their European Science Exchange Programme, and their support is gratefully acknowledged. I should also like to thank the Biologische Anstalt Helgoland for their hospitality, Dr. G. Drebes for useful discussion and interest in this work, and Ms. H. Halliger for technical assistance.

\section{LITERATURE CITED}

Cleve, P. T., 1894. Synopsis of the naviculoid diatoms. Part I. - K.svenska Vetensk-Akad. Handl. 26, $1-194$.

Cox, E. J., 1981. The use of chloroplasts and other features of the living cell in the taxonomy of naviculoid diatoms. In: Proceedings of the sixth international diatom symposium. (In press.)

Geitler, L., 1937. Der Chromatophorenbau der Diatomeen Gyrosigma und Nitzschia sigmoidea. Bot. Zbl. (Beih.) 57, 425-431.

Geitler, L., 1977. Zur Morphologie und Entwicklungsgeschichte von Eunotia-Arten (Bacillariophyceae), - Plant Syst. Evol. 127, 39-43.

Geitler, L., 1979. On some peculiarities in the life history of pennate diatoms hitherto overlooked. Am. J. Bot. 66, 91-97.

Hendey, N. I., 1964. An introductory account of the smaller algae of British coastal waters. Part V. Bacillariophyceae (Diatoms). - Fishery Invest, Lond. (Ser 4.) 5, 1-317.

Heurck, H. van, 1896. A treatise on the Diatomaceae. Wesley, London, $558 \mathrm{pp}$.

Karsten, G., 1899. Die Diatomeen der Kieler Bucht. - Wiss. Meeresunters. (Kiel) 4, $17-205$.

Karsten, G., 1928. Bacillariophyta (Diatomeae). In: Die natürlichen Pflanzenfamilien. Hrsg. von A. Engler \& K. Prantl. Engelmann, Leipzig, 2, 105-303.

McLachlan, J., 1973. Growth media-marine. In: Handbook of phycological methods, culture methods and growth measurements. Ed. by J. R. Stein. Univ. Press, Cambridge, 25-31.

Mereschkowsky, C., 1902-1903. Les types de l'endochrome chez les Diatomées. - Scripta bot. 21, $1-193$.

Paddock, T. B. B. \& Sims, P. A., 1977. A preliminary survey of the raphe structure of some advanced groups of diatoms (Epithemiaceae - Surirel aceae), - Nova Hedwigia (Beih.) 54, 291-322.

Peragallo, H. \& Peragallo, M., 1897-1908. Diat nées marines de France et des districts maritimes voisins. Tempère, Grez-sur-Loing, $491 \mathrm{pp}$.

Pritchard, A., 1861. A history of the Infusoria, including the Desmidiaceae and Diatomaceae, British and foreign. Whittaker, London, $439 \mathrm{pp}$.

Rudzki, B., 1964. Rechts-Links-Differenzierung bei Diatomeen. - Ost. bot. Z. 111, 527-529.

Schütt, F., 1896. Bacillariales (Diatomeae). In: Die natürlichen Pflanzenfamilien. Hrsg. von A. Engler \& K. Prantl. Engelmann, Leipzig, 1 (1b), 1-153.

Stoermer, E. F., Pankratz, H. S. \& Drum, R. W, 1964. The fine structure of Mastogloia grevillii Wm. Smith. - Protoplasma 59, 1-31.

Thaler, F., 1972. Beitrag zur Entwicklungsgeschichte und zum Zellbau einiger Diatomeen. - Ost. bot. Z. 120, 313-372.

VanLandingham, S. L., 1969. Catalogue of the fossil and recent genera and species of diatoms and their synonyms. Part III. Coscinophaena through Fibula. Cramer, Weinheim, 1087-1756. 